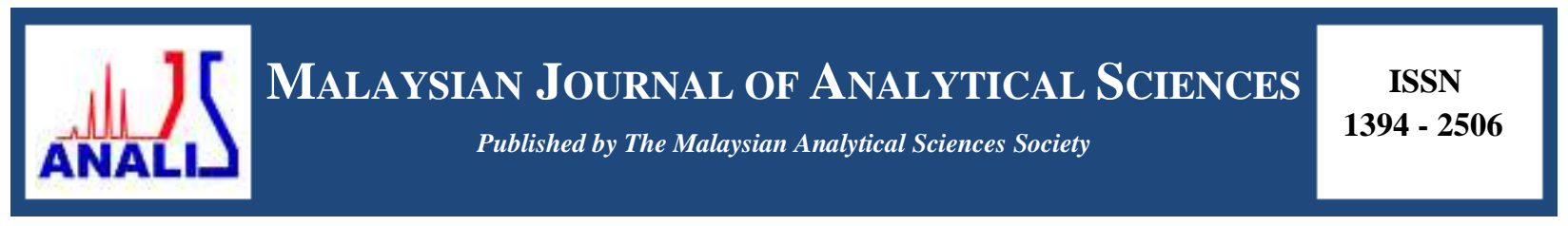

\title{
IRON AND MANGANESE REMOVAL BY NANOFILTRATION AND ULTRAFILTRATION MEMBRANES: INFLUENCE OF pH ADJUSTMENT
}

\author{
(Penyingkiran Besi dan Mangan oleh Membran Penurasan-Nano dan Penurasan-Ultra: \\ Pengaruh Pelarasan $\mathrm{pH}$ )
}

\author{
Norherdawati Kasim $^{1,3} *$, Abdul Wahab Mohammad ${ }^{1,2}$, Siti Rozaimah Sheikh Abdullah ${ }^{1}$ \\ ${ }^{I}$ Department of Chemical and Process Engineering, Faculty of Engineering and Built Environment \\ ${ }^{2}$ Research Centre for Sustainable Process Technology (CESPRO), Faculty of Engineering and Built Environment \\ Universiti Kebangsaan Malaysia, 43600 UKM Bangi, Selangor, Malaysia \\ ${ }^{3}$ Department of Chemistry, Centre for Defence Foundation Studies, \\ National Defence University of Malaysia, Kem Sg. Besi, 57000 Kuala Lumpur, Malaysia
}

*Corresponding author: herdawati@upnm.edu.my

Received: 21 October 2015; Accepted: 14 June 2016

\begin{abstract}
Iron and manganese present naturally in groundwater. Both metallic ions at excessive amounts normally contribute to rusty taste and reddish color to the water. Membrane technology may improve the conventional groundwater treatment method which commonly requires a large area and a lot of manpower. The present experimental work focused on membrane filtration of iron and manganese in order to study the influence of $\mathrm{pH}$ adjustment to the prepared artificial groundwater based on the permeate quality and membrane performances. In this study, two commercially available polyamide nanofiltration and ultrafiltration membranes (PA-NF, PA-UF) were tested to examine their capabilities in treating groundwater for drinking water resources. In order to achieve WHO drinking water standard, permeate quality of the artificial groundwater is considered satisfy if concentration of iron and manganese has reached 0.3 and $0.1 \mathrm{mg} / \mathrm{L}$, respectively. Experimental results showed that $\mathrm{pH}$ at a range of 3-11 have significantly improved membrane performance in terms of their rejection. Rejection of iron at a feed concentration of $100 \mathrm{mg} / \mathrm{L}$ increased as $\mathrm{pH}$ of the feed solution increased for all tested membranes. However, the manganese rejection with a feed concentration at $50 \mathrm{mg} / \mathrm{L}$ showed various pattern of performance for each membrane. The $\mathrm{pH}$ of feed solution played an important role in changing the membrane surface properties and also, the characteristic of solute. This concludes that solutemembrane interaction mechanism has improved the performance of the tested membranes.
\end{abstract}

Keywords: iron rejection, manganese rejection, artificial groundwater, $\mathrm{pH}$ adjustment, drinking water

Besi dan mangan wujud semulajadi di dalam air bawah tanah. Kedua-dua ion logam ini pada jumlah yang berlebihan menyumbang kepada rasa berkarat dan warna yang kemerahan pada air. Kajian ini memberi tumpuan kepada penurasan logam besi dan mangan oleh membran dengan tujuan untuk mengkaji kesan pelarasan $\mathrm{pH}$ terhadap air bawah tanah buatan berdasarkan kepada kualiti telapan dan prestasi membran. Dalam ujikaji ini, dua membran poliamida penurasan-nano dan penurasan-ultra (PA-NF, PA-UF) yang boleh didapati secara komersial telah diuji untuk mengkaji keupayaan dalam merawat air bawah tanah sebagai sumber air minuman. Untuk mencapai piawaian WHO bagi air minuman, kualiti telapan air bawah tanah buatan dianggap memuaskan jika kepekatan besi dan mangan masing-masing mencapai 0.3 dan 0.1 mg/L. Keputusan ujikaji menunjukkan bahawa $\mathrm{pH}$ di antara julat 3-11 dengan ketaranya telah menambahbaik prestasi membran dari segi penyingkiran. Penyingkiran besi pada kepekatan suapan $100 \mathrm{mg} / \mathrm{L}$ telah meningkat apabila $\mathrm{pH}$ suapan meningkat untuk semua membran yang diuji. Walau bagaimanapun, penyingkaran mangan dengan kepekatan suapan pada $50 \mathrm{mg} / \mathrm{L}$ menunjukkan kepelbagaian corak prestasi bagi setiap membran. $\mathrm{pH}$ larutan suapan memainkan peranan penting dalam mengubah sifat-sifat permukaan membran 
dan juga sifat bahan terlarut. Kesimpulannya, mekanisme interaksi bahan terlarut-membran telah meningkatkan prestasi membran yang diuji.

Kata kunci: penyingkiran besi, penyingkiran mangan, air bawah tanah, pelarasan $\mathrm{pH}$, air minuman

\section{Introduction}

Most of countries around the world rely on surface water for their daily needs including for drinking water sources. This is because surface water can be easily found over the land surface either in rivers, ponds, lakes, swamps or other fresh (not salty) sources. However, this natural water resource is more easily contaminated and contains most bacteria and other microorganism. Along with surface water, groundwater resources play a vital role in the production of clean and adequate drinking water supply all around the world. In countries such as Germany, Canada and the United States of America, nearly $70 \%$ of drinking water originates from groundwater [1]. The quality of groundwater is much better than surface water as soils, sands or rocks underneath the ground have become the filtration layers. It has been reported that most of groundwater consists some metal such as iron and manganese which naturally leach from many types of rocks and soils [2]. Iron ( $\mathrm{Fe})$ and manganese (Mn) are common metallic elements that exist together naturally especially in deeper wells [3]. Both are commonly found in water and are essential elements required in small amounts by all living organisms. Presence of excess amount of $\mathrm{Fe}$ and $\mathrm{Mn}$ resulted in metallic taste of water, slightly reddish colored water and rusty-brown stains of products like paper, cloths, and plastics [4]. World Health Organization (WHO) suggested that Fe and Mn concentrations in drinking water should be less than $0.3 \mathrm{mg} / \mathrm{L}$ and $0.1 \mathrm{mg} / \mathrm{L}$, respectively [5].

The natural occurrence of $\mathrm{Fe}$ and $\mathrm{Mn}$ in groundwater usually with very little or without existence of oxygen, typically in deeper wells, in areas where groundwater flow is slow, and also in areas where groundwater flows through soils rich in organic matter. Fe and $\mathrm{Mn}$ usually present in natural groundwater in their most soluble form as divalent ions, $\mathrm{Fe}^{2+}$ and $\mathrm{Mn}^{2+}$. In soluble form they are colorless in groundwater but when exposed to air, they get oxidized then turn to insoluble form of $\mathrm{Fe}^{3+}$ and $\mathrm{Mn}^{4+}$, respectively and leave the water with brown-red color. Several techniques have been applied to remove these metals from groundwater including ion-exchange and water softening, adsorption by activated carbon, aeration and filtration, biosorption, ionic liquid extraction, and so forth [6-10]. Recently, the application of membrane technology including nanofiltration (NF) in water treatment for producing drinking water resources has been increased rapidly. NF technology is able to overcome operational problems that used to associate with conventional technique. In addition, other advantages of NF membranes are high retention of divalent ions at lower operating pressure and higher flux with lower energy consumption.

Numerous studies have been reported in investigating the ability of membrane filtration in water treatment [11-13]. However, only a limited number of studies have examined the removal of $\mathrm{Fe}$ and $\mathrm{Mn}$ in groundwater by using NF membranes [14]. Therefore, this study was conducted with the aim to investigate the influence of operating variables on the retention of $\mathrm{Fe}$ and $\mathrm{Mn}$ in groundwater using NF membranes. Along with this membrane, the treatment was also conducted by UF membrane in order to compare their performances. In this work, $\mathrm{Fe}$ and $\mathrm{Mn}$ removal were investigated using polyamide NF and UF membrane assigned as PA-NF and PA-UF, respectively. The main objective of this study is to investigate the influence of feed solution $\mathrm{pH}$ on the prepared synthetic groundwater, quality of permeate samples and performance of the membranes. Further analysis according to surface morphology images was measured by field emission scanning electron microscopy (FESEM) to further understand the rejection mechanisms involved.

\section{Chemicals and membranes}

\section{Materials and Methods}

All of purchased chemicals were analytical grade with high purity and no further purification required before used. Ferrous chloride tetrahydrate $\left(\mathrm{FeCl}_{2} \cdot 4 \mathrm{H}_{2} \mathrm{O}\right)$ was procured from $\mathrm{HmbG}{ }^{\circledR}$ Chemicals and manganese chloride tetrahydrate $\left(\mathrm{MnCl}_{2} \cdot 4 \mathrm{H}_{2} \mathrm{O}\right)$ was obtained from Bendosen Laboratory Chemicals. In the preparation of synthetic groundwater, both chemicals were used by dissolving them in ultra-pure water with conductivity less than $1 \mu \mathrm{S} / \mathrm{cm}$ as a single component for filtration experiment. The feed solution with individual metal of Fe and $\mathrm{Mn}$ were provided at initial concentration of $100 \mathrm{mg} \mathrm{Fe} / \mathrm{L}$ and $50 \mathrm{mg} \mathrm{Mn} / \mathrm{L}$, respectively. The synthetic groundwater was freshly prepared a day before filtration experiment and kept in a cold room. This procedure was conducted to avoid 
the divalent ions from being oxidized. Ferrous iron reagent powder (HACH Permachem®, USA) was used for determination of the remaining $\mathrm{Fe}^{2+}$ ion in permeate from each filtration. Manganese reagent set (HACH Permachem ${ }^{\circledR}$, USA) consisting of buffer powder citrate type for Mn and sodium periodate were used for detection of $\mathrm{Mn}^{2+}$ in permeate samples. Individual salt solutions of sodium chloride, sodium sulphate and calcium chloride ( $\mathrm{NaCl}, \mathrm{Na}_{2} \mathrm{SO}_{4}$ and $\mathrm{CaCl}_{2}$ ) were freshly prepared using $\mathrm{NaCl}$ (Merck, Germany), $\mathrm{Na}_{2} \mathrm{SO}_{4}$ and $\mathrm{CaCl}_{2}$ (Sigma, USA). Low concentration of hydrochloric acid $(\mathrm{HCl})$ and sodium hydroxide $(\mathrm{NaOH})$ were used for $\mathrm{pH}$ adjustment on the feed solution.

Two different type of membranes were employed in order to investigate their performances for groundwater treatment, specifically for Fe and Mn removal. Both NF and UF membranes were supplied by Sterlitech Corp., USA. The polyamide (PA) flat sheet NF and UF membranes denoted as PA-NF and PA-UF, respectively were soaked overnight prior to use. The specification of the selected membranes is provided in Table 1.

Table 1. Specification of membranes

\begin{tabular}{|c|c|c|}
\hline Parameter & PA-NF & PA-UF \\
\hline Manufacturer & Koch & Osmonics \\
\hline${ }^{\mathrm{a}} \mathrm{MWCO}(\mathrm{Da})$ & 200 & 1000 \\
\hline${ }^{\mathrm{a}} \mathrm{pH}$ range at $25^{\circ} \mathrm{C}$ & $4-10$ & $2-11$ \\
\hline${ }^{\mathrm{b}}$ Contact angle $\left({ }^{\circ}\right)$ & $44 \pm 2.5$ & $66 \pm 2.5$ \\
\hline
\end{tabular}

\section{Experimental set-up}

A bench-scale dead-end stirred cell procured from Sterlitech Corporation, WA (Model HP4750) that houses a 49 $\mathrm{mm}$ diameter flat sheet membrane with effective area of $14.6 \mathrm{~cm}^{2}$ was used for filtration experiment. The filtration set-up comprises of a nitrogen gas tank, $2000 \mathrm{~mL}$ reservoir tank, $300 \mathrm{~mL}$ stainless steel stirred cell and a precision balance (Sartorious AG, Germany, Model AX6202) connected to a data acquisition personal computer. Filtration experiments by the selected membranes were conducted for 1 to 3 hour and permeate sample was collected for further water quality analysis. The remaining $\mathrm{Fe}^{2+}$ and $\mathrm{Mn}^{2+}$ ions in permeate was measured by using spectrophotometer (HACH, Model DR3900).

Filtration experiments were performed to investigate the ability of applied membranes based on permeability, flux and rejection using ultra pure water and samples of synthetic groundwater. All membranes were soaked in ultrapure water for overnight prior to use. This step was purposely to remove preservatives, and the soaking step also considered as a wetting process for the membrane. Then, compaction of membrane was conducted for 30 to 45 minutes by pressurizing the stirred cell with nitrogen gas at 5 bar without stirring. After compaction, the pure water permeability test was conducted. For determination of flux and rejection, a volume of $250 \mathrm{~mL}$ of feed solution was placed into the stirred cell and filtered for permeate sample collection.

Pure water flux was calculated by the following Eq. 1 where, $J_{w}$ is pure water flux $\left(\mathrm{L} \cdot \mathrm{h}^{-1} \cdot \mathrm{m}^{-2}\right), Q$ is amount of water collected (L) for $\Delta t(\mathrm{~h})$ which is time duration using a membrane coupon with area $A\left(\mathrm{~m}^{2}\right)$.

$$
J_{w}=\frac{Q}{A \Delta t}
$$

The flux of sample of feed solution was measured by the following Eq. 2 where $J$ is the sample flux $\left(\mathrm{L} \cdot \mathrm{h}^{-1} \cdot \mathrm{m}^{-2} \cdot \mathrm{bar}^{-1}\right)$, as a function of permeability, $L_{p}\left(\mathrm{~L} \cdot \mathrm{h}^{-1} \cdot \mathrm{m}^{-2} \cdot \mathrm{bar}^{-1}\right)$ and applied transmembrane pressure, $\Delta P$ (bar) taking the osmotic pressure difference between feed and permeate, $\Delta \pi$ (bar) into account. 


$$
J=L_{p}(\Delta P-\Delta \pi)
$$

The rejection of sample of feed solution and the removal efficiency of NF and UF membranes during the filtration was measured by Eq. 3, where $R_{\mathrm{o}}$ is the observed rejection and $C_{\mathrm{p}}$ and $C_{\mathrm{f}}$ are the concentration of permeate and feed, respectively.

$$
R_{0}=\left(1-\frac{C_{p}}{C_{f}}\right) \times 100 \%
$$

\section{Characterization of membrane}

The detail protocol for determination of characteristics of the selected commercial membranes was described in earlier publication [15]. In that publication TFC-SR3 and GHSP were referred to the PA-NF and PA-UF membrane, respectively. The hydrophilicity of membrane surface was analyzed by contact angle measurements using a static sessile drop method by goniometer contact angle (Ramé-Hart, Model 290, Netcong, USA). The analysis was conducted by using ultra-pure water dropped on top of a clean membrane surface with three series of measurement at three different spots. Images of the top surface and cross-sectional morphologies of membranes were provided by field emission scanning electron microscopy (FESEM) (Zeiss SUPRA 55VP Oberkochen, Germany). The instrument was equipped with an energy dispersive X-ray (EDX) analysis system to identify foulants that have been filtered by the membranes. The membrane pure water permeability, $L_{\mathrm{p}}$ was determined by measurement of water flux at operating pressure ranged of 1 to 5 bar using ultra-pure water at conductivity less than $1 \mu \mathrm{S} / \mathrm{cm}$ and conducted at room temperature. Membranes were immersed in ultra-pure water and kept for overnight before compaction at 5 bar for 30 to 45 min prior to use.

\section{Iron and manganese ion analysis}

Permeate samples of Fe and Mn were analyzed using spectrophotometer (HACH, USA, Model DR3900). The collected permeate after filtration process was checked for water quality analysis in identifying the best operating variables to meet the drinking water standards. Physico-chemical parameters were measured to investigate the efficiency of membranes. Conductivity, $\mathrm{pH}$ and TDS were measured using $\mathrm{pH} / \mathrm{EC} / \mathrm{TDS}$ benchtop meter (HANNA, UK, Model HI-2550), whereas turbidity were analyzed by using turbidimeter (HACH, USA, Model 2100AN). Color, Fe and $\mathrm{Mn}$ in permeate were detected by using spectrophotometer (HACH, Model DR3900). All parameters were analyzed according to the APHA standard methods.

\section{Results and Discussio
ranes: Water flux}

Three different coupons of PA-NF and PA-UF were used for measurement of water fluxes. The average volumetric water flux at applied pressure of 5.0 bar for PA-NF membrane was found $10.75 \pm 0.5 \mathrm{~L} \mathrm{~m}^{-2} \mathrm{~h}^{-1}$. The result obtained was lesser than the PA-UF membrane flux at $15.85 \pm 0.5 \mathrm{~L} \mathrm{~m}^{-2} \mathrm{~h}^{-1}$. From the observed results, these indicated that all coupons of PA-NF and PA-UF membranes conducted for this objective have permeability of $2.15 \pm 0.5 \mathrm{~L}$ $\mathrm{m}^{-2} \mathrm{~h}^{-1} \mathrm{bar}^{-1}$ and $3.17 \pm 0.5 \mathrm{~L} \mathrm{~m}^{-2} \mathrm{~h}^{-1} \mathrm{bar}^{-1}$, respectively. These results showed that the separation layer of PA-UF membrane was more permeable to water in comparison to PA-NF. Data obtained from manufacturer had reported that the molecular weight cut off for PA-NF and PA-UF were 200 and $1000 \mathrm{Da}$, respectively. Therefore, results of water flux were congruent with the specification of PA-NF and PA-UF membranes. Data of water fluxes is presented in Table 2 for comparison.

\section{Hydrophilicity}

The hydrophilicity of membranes was measured by static sessile drop method. The contact angle between pure water droplet and the clean surface of membrane is a measurement of wettability of membranes. The higher value of contact angle indicates that the membrane is more hydrophobic. Three series of measurement at three different spots of clean membranes were conducted a day after the samples were kept overnight in a desiccator. The average contact angles of three clean membrane coupons for each PA-NF and PA-UF was found at $44^{\circ} \pm 2.5$ and $66^{\circ} \pm 2.5$, respectively. Results showed that PA-NF is more hydrophilic than PA-UF membrane. The findings of contact angle 
of the selected NF and UF membranes in this study revealed that both membranes were suitable for further application in treating groundwater. However, the potential of both membranes in rejecting contaminants and meeting the drinking water standard should be the main priority.

Table 2. Water permeability test of NF and UF membranes

\begin{tabular}{lll}
\hline Parameter & PA-NF & PA-UF \\
\hline $\begin{array}{l}\text { Average volumetric water flux } \\
\left(\mathrm{L} \cdot \mathrm{m}^{-2} \cdot \mathrm{h}^{-1}\right)\end{array}$ & $10.75 \pm 0.5$ & $15.85 \pm 0.5$ \\
$\begin{array}{l}\text { Membrane permeability } \\
\left(\mathrm{L} \cdot \mathrm{m}^{-2} \cdot \mathrm{h}^{-1} \cdot \mathrm{bar}^{-1}\right)\end{array}$ & $2.15 \pm 0.5$ & $3.17 \pm 0.5$ \\
\hline
\end{tabular}

\section{Effect of pH on solute and membrane}

The prepared synthetic groundwater containing of $\mathrm{Fe}^{2+}$ and $\mathrm{Mn}^{2+}$ ions was added with low concentration $(0.1 \mathrm{M})$ of hydrochloric acid $(\mathrm{HCl})$ or sodium hydroxide $(\mathrm{NaOH})$ in order to adjust the $\mathrm{pH}$ of feed solution in the range of $\mathrm{pH} 3$ to 11 . Fig. 1 represents the physical observation on the feed solution of synthetic groundwater at $\mathrm{pH} 9$ prepared for filtration experiment. This result is used to further show that there was color changed in the feed solution as the solute has transformed from lower to higher oxidation state.
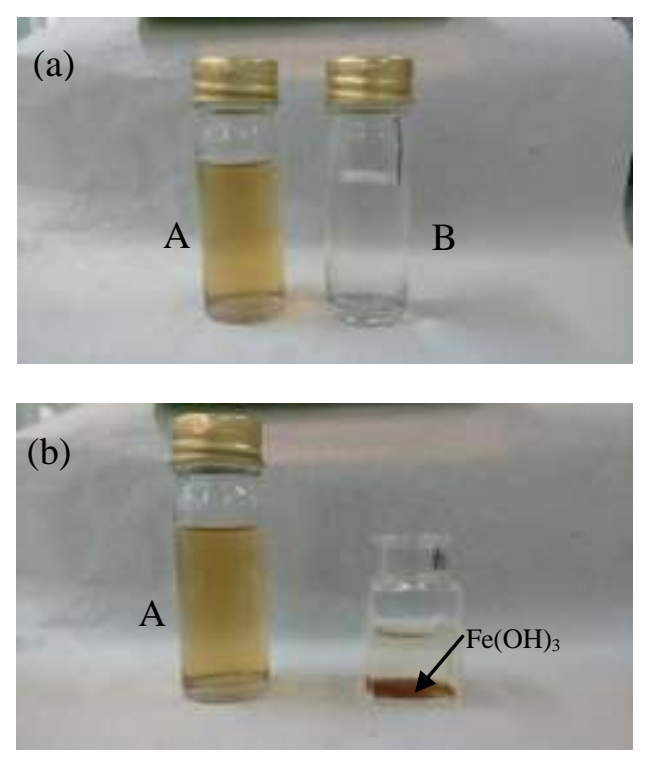

Figure 1. Physical properties of $100 \mathrm{mg} \mathrm{Fe} / \mathrm{L}$ (a) at feed $\mathrm{pH} 9.3$ (sample A), pH 6.5 (sample B) and (b) when $\mathrm{Fe}(\mathrm{OH})_{3}$ formed as flocs

Insoluble trivalent ferric ions, $\mathrm{Fe}^{3+}$ or known as iron solid commonly occur as colourful bright reddish-yellow to yellowish-brown stains as in sample A in Fig. 1(a). When sample A was exposed to air at ambient temperature for about 10 to 20 minutes, precipitate of iron hydroxide $\left(\mathrm{Fe}(\mathrm{OH})_{3}\right)$ was settled down at the bottom of cell as shown in Fig. 1(b). The initial $\mathrm{pH}$ of $\mathrm{FeCl}_{2}$ and $\mathrm{MnCl}_{2}$ feed solution right after preparation of the synthetic groundwater was found at $6.0 \pm 0.5$. At this condition, both divalent metal ions were soluble in water, with the prepared synthetic groundwater samples consist of either $\mathrm{Fe}^{2+}$ or $\mathrm{Mn}^{2+}$ ions were colourless as sample B in Figure 1(a). By increasing the $\mathrm{pH}$, the soluble divalent ions were slowly oxidized to become insoluble and stable ions as the following Eq. 4 and Eq. 5; 


$$
\begin{gathered}
\mathrm{Fe}^{2+}+3 \mathrm{H}_{2} \mathrm{O} \rightarrow \mathrm{Fe}(\mathrm{OH})_{\mathrm{a}}+3 \mathrm{H}^{+}+\mathrm{e}^{-} \\
\mathrm{Mn}^{2+}+2 \mathrm{H}_{2} \mathrm{O} \rightarrow \mathrm{MnO}_{2}+4 \mathrm{H}^{+}+2 \mathrm{e}^{-}
\end{gathered}
$$

The stability of $\mathrm{Fe}^{2+}$ ions depend not only on $\mathrm{pH}$ but also on the activity of electrons. The occurrence and behaviour of $\mathrm{Mn}^{2+}$ ions is not similar to $\mathrm{Fe}$. It was found that $\mathrm{Fe}^{2+}$ is more easily and rapidly oxidized than $\mathrm{Mn}^{2+}$. Precipitation of $\mathrm{Fe}(\mathrm{OH})_{3}$ and $\mathrm{MnO}_{2}$ was due to the feed solution having bigger size of particles formed once the $\mathrm{pH}$ feed solution has increased. Therefore, size exclusion was expected to be the domain rejection mechanism for feed solution at higher $\mathrm{pH}$ and membrane performance has been significantly influenced by the feed $\mathrm{pH}$ adjustment.

\section{Permeate quality}

Fig. 2(a) presents the permeate concentrations measured after filtration experiments using feed solution with $100 \mathrm{mg}$ $\mathrm{Fe} / \mathrm{L}$ at adjustment of $\mathrm{pH}$ in the range of $\mathrm{pH} 3$ to 11 . Results show that at these $\mathrm{pH}$ range, the concentration of metallic ions detected in permeate decreased with increasing $\mathrm{pH}$. For Fe removal by PA-NF membrane at $\mathrm{pH} 9$ and 11 , permeate concentration measured were well below than the acceptable limit for drinking water standard set by WHO which were 0.08 and $0.12 \mathrm{mg} \mathrm{Fe} / \mathrm{L}$, respectively. Whereas by using PA-UF membrane, results showed that the permeate quality $(0.12,0.07$ and $0.13 \mathrm{mg} \mathrm{Fe} / \mathrm{L})$ was satisfied when feed solution used were at $\mathrm{pH} 7,9$ and 11 . These results indicated that $\mathrm{Fe}$ rejection was succesful at $\mathrm{pH} 9$ and above. It was found that poor rejection of Fe by both NF and UF membranes when feed solution $\mathrm{pH}$ was adjusted below 7. Thus, results proved that $\mathrm{pH}$ has importantly impacted Fe removal as also reported by other scholars [16]. The feed $\mathrm{pH}$ may change the nature of the membrane surface charge and pore size, as well as the dissolved metal species and therefore can affect the membrane separation efficiency [17]. Between $\mathrm{pH} 3$ and 7, almost all $\mathrm{Fe}$ present as soluble $\mathrm{Fe}^{2+}$. Higher than $\mathrm{pH} 8$, $\mathrm{Fe}$ is predominantly present as insoluble $\mathrm{Fe}^{3+}$ and easily precipitate as $\mathrm{Fe}(\mathrm{OH})_{3}$ on the surface of membrane. Therefore, Fe removal at this point were mainly by size exclusion (seiving effect).
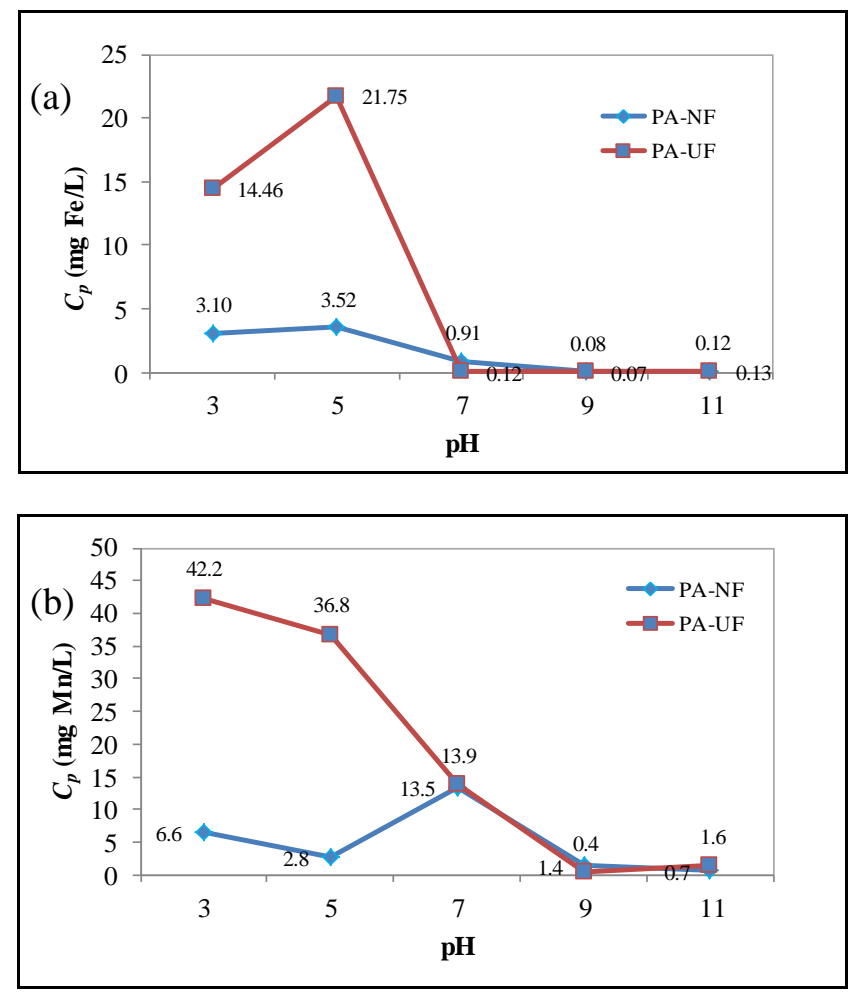

Figure 2. Effect of $\mathrm{pH}$ on permeate concentration for filtration of (a) Fe and (b) Mn from synthetic groundwater 
For Mn removal with feed concentration at $50 \mathrm{mg} \mathrm{Mn} / \mathrm{L}$, it was found that the best quality of permeate achieved when using feed solution at $\mathrm{pH} 9$ with detected permeate concentration at $0.4 \mathrm{mg} \mathrm{Mn} / \mathrm{L}$ as shown in Fig. 2(b). This value was achieved by filtration using PA-NF membrane. However, it was considered as unsatisfied as for drinking water since the acceptable value should be at least $0.1 \mathrm{mg} \mathrm{Mn} / \mathrm{L}$. Poor quality of permeate at below than $\mathrm{pH} 9$ especially by PA-UF membrane probably attributed by the effect of concentration polarization. The occurence and behavior of $\mathrm{Mn}$ is not similar to $\mathrm{Fe}$, as $\mathrm{Fe}^{2+}$ ions were easily and rapidly oxidized than $\mathrm{Mn}^{2+}$ ions. At higher than $\mathrm{pH} 9, \mathrm{Mn}$ is slowly exist as stable $\mathrm{Mn}^{4+}$ and insoluble as $\mathrm{MnO}_{2}$ which then precipitate on the surface of membrane or blocked in the pores. At this point, Mn removal could be attributed solely by size exclusion. Between $\mathrm{pH} 3$ and 7 , Mn exist as soluble $\mathrm{Mn}^{2+}$ and thus, easily permeate and pass through membrane pores. As a result, poor rejection occured especially at $\mathrm{pH} 3$ with high value of permeate concentration at $42.2 \mathrm{mg} \mathrm{Mn} / \mathrm{L}$ was detected. In acidic feed solution, membrane pores could be expanded. At this point, PA-NF was reported to be positively charged. Low retention at $\mathrm{pH} 3$ explained that solute-membrane interaction is the main mechanism and dominated by the nature of membrane pores.

\section{Rejection}

Fig. 3 presents the effect of feed $\mathrm{pH}$ on Fe and Mn rejection by using PA-NF and PA-UF membrane. In general, as the $\mathrm{pH}$ increased from 3 to 11 , the rejection of these metallic ions inreased. This can be mainly caused by the solutemembrane charges interaction. It is obviously showed that rejection of $\mathrm{Fe}$ at various feed $\mathrm{pH}$ were higher than $\mathrm{Mn}$. Lower rejection of $\mathrm{Mn}$ could be attributed solely to the electrostactic effect interaction between membrane material and $\mathrm{Mn}^{2+}$ ions [18]. The isoelectric point (IEP) of PA-NF is in the range of 6 to 8 as reported by De Munari et al. [19]. This membrane is characterized as an amphoteric membrane whereby it is positively charged in solution less than $\mathrm{pH} 6$ and negatively charged in solution more than $\mathrm{pH}$ 8. Between $\mathrm{pH} 3$ and 5, the membrane is positively charged and lower Fe rejection could be due to dissolved $\mathrm{Fe}^{2+}$ were easily permeate the membrane pores. Thus, charge repulsion and size exclusion are less important at this feed $\mathrm{pH}$ range. At $\mathrm{pH}$ 7, high Fe rejection mainly because of electrostatic interaction between the membrane and the ions was zero. Therefore, the ions did not easily permeate through the membrane and contribute to higher rejection of Fe at IEP of membrane.
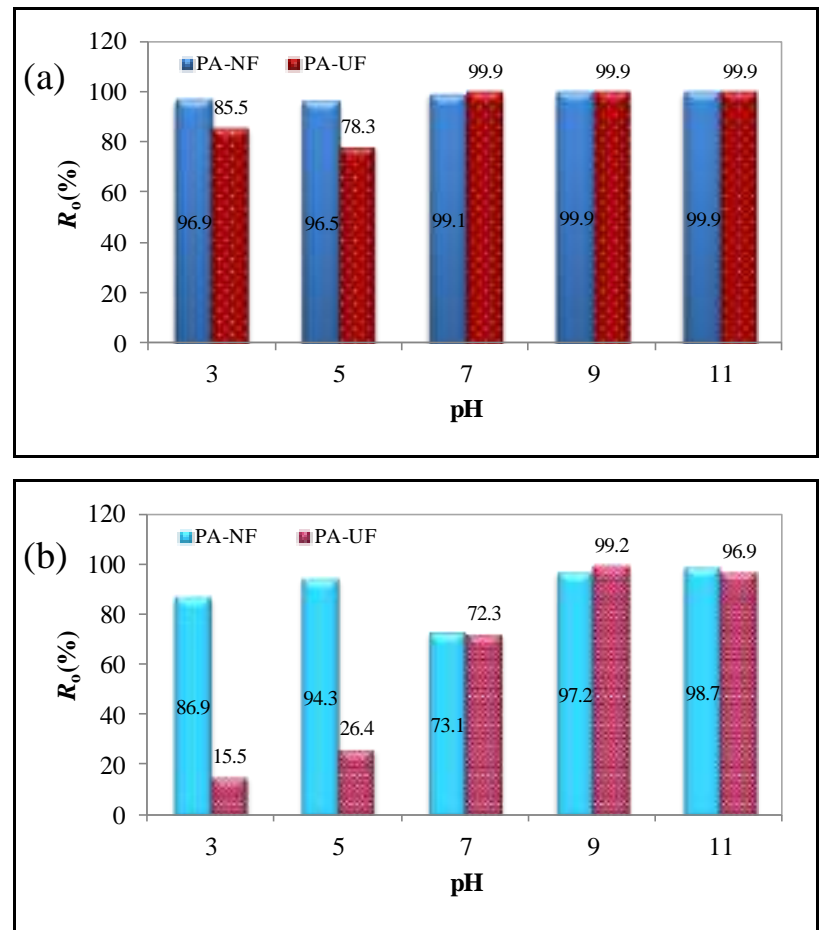

Figure 3. Rejection of (a) $\mathrm{Fe}$ and (b) at various feed $\mathrm{pH}$ by using $100 \mathrm{mg} \mathrm{Fe} / \mathrm{L}$ and $50 \mathrm{mg} \mathrm{Mn} / \mathrm{L}, 5$ bar, $25{ }^{\circ} \mathrm{C}$ with $500 \mathrm{rpm}$ stirring rate 
The $\mathrm{pH}$ of feed solution may change the nature of the membrane surface charge and pore size, as well as that of dissolved metal species and therefore can affect the membrane separation efficiency. PA-NF membrane has reached higher rejection rate for both metals in comparison with PA-UF as depicted in Fig. 3(a) and 3(b), respectively. Similar findings for Fe removal has previously been reported by Jusoh et al. [7] and De Munari et al. [19]. Regarding to $\mathrm{Mn}^{2+}$ ions, De Munari and Schafer [14] reported that PA-NF membrane has achieved more than 95\% of rejection at pH 7. In Fig. 3(b), Mn rejection at $\mathrm{pH} 7$ has inreased very well to $>70 \%$ from $26 \%$ rejection at $\mathrm{pH} 5$. At $\mathrm{pH}$ 9, higher $\mathrm{Mn}$ rejection was achieved to more than $95 \%$ and mainly because of changes of solute charges to a stable form which easily removed by membrane as further explained in the earlier section. The good rejection at this condition was mainly contributed by solute-membrane charge interactions. The charge of solute influenced the extent of rejection by NF membranes though the precise mechanism of rejection will depend upon the particular membrane in use [20].

\section{Surface morphology analysis}

An image of fouled PA-NF membranes for filtration of single metal component in synthetic groundwater at $\mathrm{pH} 9$ is presented in Fig. 4. From visual observation, brownish cake layer become visible on top surface of membrane (PA$\mathrm{NF})_{\mathrm{A}}$, resulted from Fe removal. Whereas, blackish cake layer formed on the surface of membrane (PA-NF) $)_{B}$ after filtration with synthetic groundwater solution with $\mathrm{Mn}$ ions. The cake layer formed mainly because of precipitation of $\mathrm{Fe}(\mathrm{OH})_{3}$ and $\mathrm{MnO}_{2}$ as explained in the earlier section. Bordoloi et al. [21] reported that the SEM image with EDS analysis of arsenic (As) and iron ( $\mathrm{Fe}$ ) removal from groundwater by oxidation-coagulation at optimized $\mathrm{pH}$ revealed that the sorption of As onto the poorly crystalline precipitate of $\mathrm{Fe}(\mathrm{OH})_{3}$ and existence of a small amount of $\mathrm{MnO}_{2}$. The FESEM images of the precipitate obtained in the presence of Fe and Mn for filtration by both PA-NF and PAUF membranes at adjusted $\mathrm{pH}$ of feed solutions are depicted in Figure 5. The precipitates of $\mathrm{Fe}(\mathrm{OH})_{3}$ on PA-NF and PA-UF membranes are presented by Fig. 5(a) and 5(c), respectively. Whereas, Fig. 5(b) and 5(d) indicate the precipitate of $\mathrm{MnO}_{2}$ on the PA-NF and PA-UF membranes with aggregated large regularly shaped particles suggestive of stable crystallinity of precipitate. In comparison to $\mathrm{Fe}(\mathrm{OH})_{3}, \mathrm{MnO}_{2}$ was found more stable especially at $\mathrm{pH}$ higher than 8 .

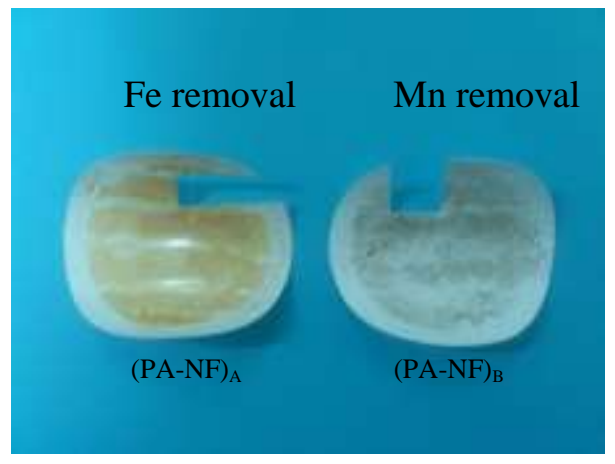

Figure 4. Visualization on physical quality of fouled PA-NF membranes for filtration at 5 bar and $\mathrm{pH} 9$ 

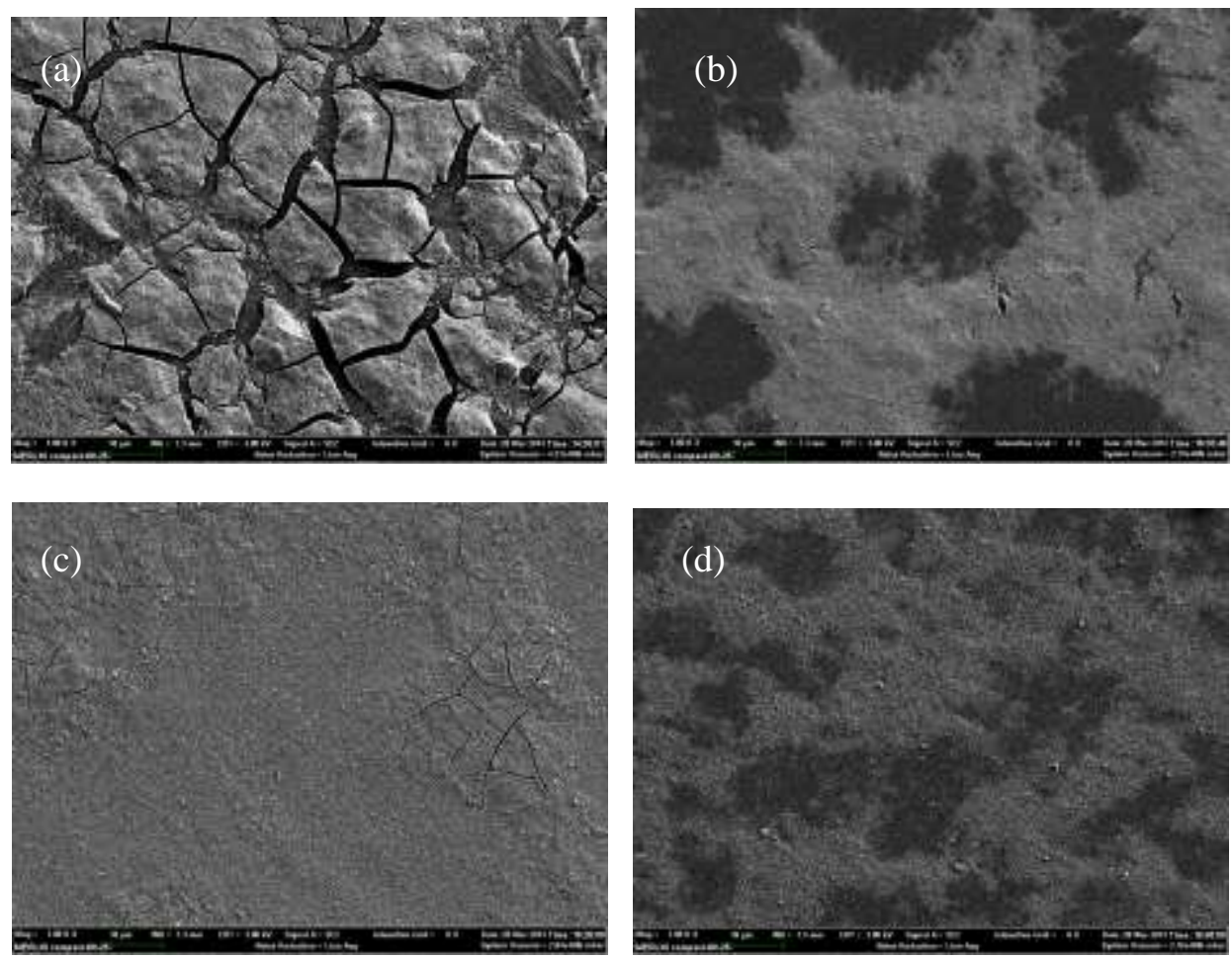

Figure 5. FESEM image of (a) $\mathrm{Fe}(\mathrm{OH})_{3}$ (b) $\mathrm{MnO}_{2}$ on PA-NF, and (c) $\mathrm{Fe}(\mathrm{OH})_{3}$ (d) $\mathrm{MnO}_{2}$ on PA-UF membranes

\section{Conclusion}

The solute-membrane interaction during removal of iron and manganese from synthetic groundwater were investigated in this study. The rejection mechanism of both metallic ions by using PA-NF and PA-UF membranes were also identified and evaluated in this work. The main focus for this paper was to inspect the effect of adjustment on the initial $\mathrm{pH}$ of feed solution mainly on the rejection behaviour, permeate quality towards meeting the drinking water standard and also changes on solubility of solute in feed solution. The efficiencies of these membranes were assessed based on permeability, water flux and rejection capabilities at 5 bar and $\mathrm{pH}$ of feed solution ( $\mathrm{pH} 3$ - 11). The rejection for metallic ions $\left(\mathrm{Fe}^{2+}\right.$ and $\mathrm{Mn}^{2+}$ ) in artificial groundwater using these membranes were significantly influenced by the adjustment of $\mathrm{pH}$. Particularly, rejections of both metals by PA-NF were found higher than PAUF for all cases. In addition, results proved that PA-NF membrane had efficiently rejected $\mathrm{Fe}^{2+}$ and $\mathrm{Mn}^{2+}$ ions to the allowable value for drinking water based on WHO standards. Excellent separation performance of PA-NF membrane was mainly due to its effective separation layer of membrane structure.

The significant contribution of solute-membrane charge interactions was determined and influenced by the initial $\mathrm{pH}$ of feed solution. It was observed that an increase of $\mathrm{pH}$ determined a higher efficiency of Fe and $\mathrm{Mn}$ rejections by PA-NF membrane. Higher $\mathrm{pH}$ of the feed solution contributed to transformation of soluble divalent $\mathrm{Fe}^{2+}$ and $\mathrm{Mn}^{2+}$ ions to insoluble $\mathrm{Fe}^{3+}$ and $\mathrm{Mn}^{4+}$ ions which were more stable and easily precipitated on membrane surfaces. The increase of feed solution $\mathrm{pH}$ has decreased the solubility of the divalent metallic ions $\left(\mathrm{Fe}^{2+}\right.$ and $\left.\mathrm{Mn}^{2+}\right)$. Therefore, flocculation of metallic ions in the feed solution as the $\mathrm{pH}$ increased has resulted to higher rejection of the metal components from the synthetic groundwater. In conclusion, all findings in this study contributed to possibility of developing the membrane technology for Malaysia's groundwater treatment specifically in the removal of $\mathrm{Fe}$ and $\mathrm{Mn}$ for clean and safe drinking water resources. 


\section{Acknowledgement}

The authors would like to thank Universiti Kebangsaan Malaysia by the grant ICONIC-2013-002 for financial supports. Additionally, the first author is gratefully wished special thanks to the Ministry of Higher Education Malaysia and also the National Defence University of Malaysia for funding the scholarship.

\section{References}

1. Filip, Z. and Demnerova, K. (2009). Survival in groundwater and FT-IR characterization of some pathogenic and indicator bacteria. Threats to Global Water Security: 117 - 122.

2. Stewardship, W., Series, I. (2007). Iron \& manganese in groundwater, Br. Columbia Groundwater Association.

3. Ahmad, M. (2012). Iron and manganese removal from groundwater, Thesis University of Oslo.

4. Marchovecchio, R. H., Botte, J. E. and Freiji, S. E (2011). Heavy metals, major metals, trace elements, in: Handbook Water Analysis, CRC Press.

5. World Health Organization, WHO. (2008). Guidelines for drinking-water quality, in: Recomendations, Volume1, 3rd edition, World Health Organization, Geneva: pp. 390 - 399.

6. Chaturvedi, S. and Dave, P. N. (2012). Removal of iron for safe drinking water. Desalination, 303: 1-11.

7. Jusoh, A., Cheng, W. H., Low, W. M., Nora'aini, A. and Megat Mohd Noor, M. J. (2005). Study on the removal of iron and manganese in groundwater by granular activated carbon. Desalination, 182: 347 -353.

8. Ellis, D., Bouchard, C. and Lantagne, G. (2000) Removal of iron and manganese from groundwater by oxidation and microfiltration. Desalination, 130: $255-264$.

9. Abdul Kadir, A., Othman, N. B. and Azmi, N. M (2012). Potential of using Rosa Centifolia to remove iron and manganese in groundwater treatment. International Journal of Sustainable Construction Engineering Technology, 3: $70-82$.

10. Hussin, N. H., Yusoff, I., Alias, Y., Mohamad S., Rahim, N.Y. and Ashraf, M. A. (2013). Ionic liquid as a medium to remove iron and other metal ions: A case study of the North Kelantan Aquifer, Malaysia. Environmental Earth Science, 71: $2105-2113$.

11. Choo, K.-H., Lee, H and Choi., S.-J. (2005). Iron and manganese removal and membrane fouling during UF in conjunction with prechlorination for drinking water treatment. Journal of Membrane Science, 267: 18 - 26.

12. Potgieter, J. H., Mccrindle R. I., Sihlali, Z., Schwarzer R. and Basson, N. (2005). Removal of iron and manganese from water a high organic carbon loading part I : The effect of various coagulants. Water, Air Soil Pollution, 162: 49 - 59.

13. Lin, J. L., Huang, C., Pan, J. R. and Wang, Y. S. (2013). Fouling mitigation of a dead-end microfiltration by mixing-enhanced preoxidation for Fe and Mn removal from groundwater. Colloids Surfaces A Physicochemical and Engineering Aspects, 419: 87 - 93.

14. De Munari, A. and Schäfer, A. I. (2010). Impact of speciation on removal of manganese and organic matter by nanofiltration. Journal of Water Supply Research and Technology Aqua, 59 : $152-163$.

15. Kasim, N., Mohammad, A.W. and Abdullah, S. R. S. (2015). Characterization of hydrophilic nanofiltration and ultrafiltration membranes for groundwater treatment as potable water resources. Desalination and Water Treatment, 57(17): $7711-7720$.

16. Bordoloi, S., Nath, M. and Dutta, R. K. (2013). pH-conditioning for simultaneous removal of arsenic and iron ions from groundwater. Process Safety and Environmental Protection, 91: 405 - 414.

17. Al-Rashdi, B. A. M., Johnson, D. J. and Hilal, N. (2013). Removal of heavy metal ions by nanofiltration. Desalination, 315: 2 - 17.

18. Kabsch-Korbutowicz, M. and Winnicki, T. (1996). Application of modified polysulfone membranes to the treatment of water solutions containing humic substances and metal ions. Desalination, 105: $41-49$.

19. De Munari, A., Semiao, A. J. C. and Antizar-Ladislao, B. (2013). Retention of pesticide endosulfan by nanofiltration: Influence of organic matter-pesticide complexation and solute-membrane interactions. Water Research, 47: $3484-3496$.

20. Waite, T. D. (2005). Chemical speciation effects in nanofiltration separation, in: T.D. Schäfer, Andrea I., Fane, A.G., Waite (Ed.), Nanofiltration-principles Application. Elsevier B.V.: pp. 148 - 168.

21. Bordoloi, S., Nath, S. K., Gogoi, S. and Dutta, R. K. (2013). Arsenic and iron removal from groundwater by oxidation-coagulation at optimized pH: Laboratory and field studies. Journal of Hazardous Materials, 260: 618 $-626$. 